Int. J. Dev. Biol. 58: 163-174 (2014)

doi: $10.1387 / \mathrm{ijdb} .140074 \mathrm{bm}$

\title{
Embryonic diapause: development on hold
}

\author{
JANE C. FENELON, ARNAB BANERJEE and BRUCE D. MURPHY* \\ Centre de Recherche en Reproduction Animale, Université de Montréal, St-Hyacinthe QC Canada
}

\begin{abstract}
Embryonic diapause, the temporary suspension of development of the embryo, is a fascinating reproductive strategy that has been frequently exploited across the animal kingdom. It is characterized by an arrest in development that occurs at the blastocyst stage in over 130 species of mammals. Its presumed function is to uncouple mating from parturition, to ensure that both occur at the most propitious moment for survival of the species. Diapause can be facultative, i.e. induced by physiological conditions, or obligate, i.e. present in every gestation of a species. In the latter case, the proximal signals for regulation are related to photoperiod. Three diverse models, the mouse, the mustelid carnivores and the wallaby have been studied in detail. From these studies it can be discerned that, although the endocrine cues responsible for induction of diapause and re-initiation of development vary widely between species, there are a number of commonalities. Evidence to date indicates that the uterus exercises the proximal regulatory influence over whether an embryo enters into and when it exits from diapause. Some factors have been identified that appear crucial to this regulation, in particular, the polyamines. Recent studies indicate that diapause can be induced in species where it does not exist in nature. This suggests that the potential for diapause in mammals to be due to a single evolutionary event, to which control mechanisms adapted when the trait was beneficial to reproductive success. Further work at the molecular, cellular and organismic levels will be required before the physiological basis of diapause is resolved.
\end{abstract}

KEY WORDS: blastocyst, diapause, polyamine, evolutionary strategy

\section{Introduction}

Reversible arrest of embryo development occurs across the animal kingdom, with multiple examples in nematodes, insects, non-mammalian vertebrates and mammals. The phenomenon, known as embryonic diapause, has intrigued biologists of several stripes, from those focused on evolution, to embryologists, endocrinologists and animal scientists. The first recorded observation of diapause is found in the field notes of William Harvey (1578-1657), who accompanied King Charles I on hunts of roe deer, where he observed differential states of embryonic development following examination of uterine contents (Hunter, 1995). The first report in scientific literature for mammals appears to be that of Bischoff in 1854 , on the roe deer (cited in Sempere, 1977), followed by that of Lataste in 1891, who showed lengthened gestation in female rodents suckling large litters (cited in Psychoyos, 1992). In rodents and in many other mammalian species (Table 1), the embryo is arrested at the blastocyst stage for variant intervals that are specific to the species and to the environmental conditions. A similar strategy known as delayed development is found in bats, whereby the blastocyst implants superficially, then grows very slowly, re- sulting in long and variable gestation lengths (Heideman, 1989). Although there are some detracting hypotheses, the consensus view of the significance of embryonic diapause as an evolutionary strategy is that it allows the uncoupling of fertilization from birth, thereby ensuring that postnatal development occurs under the most favorable environmental conditions for survival of the offspring (Lindenfors et al., 2003).

Embryonic diapause has been identified in over 130 mammalian species (Table 1) and the range of external mechanisms and processes acting on the uterine environment during this time can differ significantly amongst species. Despite this, many of the molecular controls of embryonic diapause appear to have been conserved. However, the precise mechanisms by which the uterus exerts its influence on the embryo are still not clearly understood.

\footnotetext{
Abbreviations used in this paper: $\mathrm{CB} 1, \mathrm{CB} 2$, Cannabinoid receptors; Esr1, Estrogen receptor- $\alpha$; Esr2, Estrogen receptor- $\beta$; FGF, Fibroblast growth factor; HBEGF, Heparin binding epidermal growth factor; IL1B, Interleukin 1 $\beta$; LIF, Leukemia inhibitory factor; miRNA, MicroRNA; Msx1, Muscle segment homeobox-1; Msx2, Muscle segment homeobox-2; ODC1, Ornithine decarboxylase; Pgr, Progesterone receptor; Wnt, Wingless gene family.
}

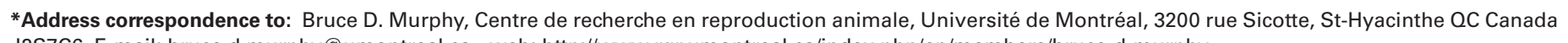
J2S7C6. E-mail: bruce.d.murphy@umontreal.ca - web: http://www.rqr.umontreal.ca/index.php/en/members/bruce-d-murphy 
Furthermore, since it is unknown whether the evolution of diapause was a single event or if it evolved multiple times, it is unclear to what extent the mechanisms by which the embryo-uterine dialogue coordinates the events of diapause are conserved across species.

These cautions notwithstanding, the study of embryonic dia- pause has the potential to provide us with a greater understanding of many aspects of early embryo development. For example, determining how an embryo is able to remain quiescent for an extended period of time could elucidate the minimum factors required for embryo survival both in vivo and in vitro. Similarly,

TABLE 1

\section{LIST OF CURRENTLY KNOWN SPECIES WITH PRE-IMPLANTATION EMBRYONIC DIAPAUSE}

\begin{tabular}{|c|c|c|c|c|c|c|c|}
\hline Order & Family & Common name & Species & Order & Family & Common name & Species \\
\hline OBLIGATE & & & & FACULTATIVE & & & \\
\hline EUTHERIA & & & & Eulipotyphla & Soricidae & Eurasian water shrew & Neomys fodiens \\
\hline Artiodactyla & Cervidae & Roe deer & Capreolus capreolus & & & Common shrew & Sorex araneus \\
\hline Carnivora & Mephitidae & Hooded skunk & Mephitis macroura & Rodentia & Cricetidae & $\begin{array}{l}\text { Pygmy shrew } \\
\text { Red tree vole }\end{array}$ & $\begin{array}{l}\text { Sorex minutus } \\
\text { Arborimus longicaudus }\end{array}$ \\
\hline & & Striped skunk & Mephitis mephitis & nucuentia & Cilcetuat & Small vesper mouse & Calomys laucha \\
\hline & & Western spotted skunk & Spilogale gracilis & & & Northern collared lemming & Dicrostonyx groenlandicus \\
\hline & Mustelidae & Hog-badger & Arctonyx collaris & & & $\begin{array}{l}\text { Field vole } \\
\text { Pats }\end{array}$ & Microtus agrestis \\
\hline & & American hog-nosed skunk & Conepatus mesoleucus & & & Bank vole & Myodes glareolus \\
\hline & & $\begin{array}{l}\text { Sea otter } \\
\text { Wolverine }\end{array}$ & $\begin{array}{l}\text { Enhydra lutris } \\
\text { Gulo gulo }\end{array}$ & & & Northern grasshopper & Onychomys leucogaster \\
\hline & & North American otter & Lontra canadensis & & & mouse & Peromvscus gossvpinus \\
\hline & & Neotropical river otter & Lontra longicaudis & & & $\begin{array}{l}\text { Cotton mouse } \\
\text { White-footed mouse }\end{array}$ & $\begin{array}{l}\text { Peromyscus gossypinus } \\
\text { Peromyscus leucopus }\end{array}$ \\
\hline & & American marten & Martes americana & & & Deer mouse & Peromyscus maniculatus \\
\hline & & Yellow-throated marten & Martes flavigula & & & Pinyon mouse & Peromyscus truei \\
\hline & & Beech marten & Martes foina & & & Campbell's hamster & Phodopus campbelli \\
\hline & & Nilgiri marten & Martes gwatkinsii & & & Dzhungarian hamster & Phodopus sungorus \\
\hline & & European pine marten & Martes martes & & & Chiriqui brown mouse & Scotinomys xerampelinus \\
\hline & & Japanese marten & Martes melampus & & Muridae & Lesser short-tailed gerbil & Gerbillus simoni \\
\hline & & Fisher & Martes pennanti & & & Common water rat & Hydromys chrysogaster \\
\hline & & Sable & Martes zibellina & & & Natal mastomys & Mastomys natalensis \\
\hline & & European badger & Meles meles & & & Sundevall's jird & Meriones crassus \\
\hline & & Honey badger & Mellivora capensis & & & Shaw's jird & Meriones shawi \\
\hline & & Short tailed weasel (stoat) & Mustela erminea & & & Mongolian gerbil & Meriones unguiculatus \\
\hline & & Long tailed weasel & Mustela frenata & & & House mouse & Mus musculus \\
\hline & & European mink & Mustela lutreola & & & Spinifex hopping mouse & Notomys alexis \\
\hline & & American mink & Neovison vison & & & Fawn hopping mouse & Notomys cervinus \\
\hline & & $\begin{array}{l}\text { American badger } \\
\text { European marbled polecat }\end{array}$ & Taxidea taxus & & & Sandy island mouse & Pseudomys \\
\hline & Odobenidae & Walrus & $\begin{array}{l}\text { Vormela peregusna } \\
\text { Odobenus rosmarus }\end{array}$ & & & New holland mouse & hermannsburgenesis \\
\hline & Otariidae & New Zealand fur seal & Arctocephalus forsteri & & & $\begin{array}{l}\text { New holland mouse } \\
\text { Bush rat }\end{array}$ & $\begin{array}{l}\text { Pseudomys novaehollandiae } \\
\text { Rattus fuscipes }\end{array}$ \\
\hline & & Antarctic fur seal & Arctocephalus gazella & & & Brown rat & Rattus norvegicus \\
\hline & & South African fur seal & Arctocephalus pusillus & & & Indian gerbil & Tatera indica \\
\hline & & Subantarctic fur seal & Arctocephalus tropicalis & MARSUPIALIA & & & \\
\hline & & Stellar sea lion & Eumetopias jubatus & Dasyuromorphia & Dasyuridae & Brown antechinus & Antechinus stuartii \\
\hline & & Australian sea lion & Neophoca cinerea & Diprotodontia & Acrobatidae & Feathertail glider & Acrobates pygmaeus \\
\hline & & Southern sea lion & Otaria byronia & & & Feathertail possum & Distoeuchurus pennatus \\
\hline & & California sea lion & Zalophus californianus & & Burramyidae & Western pygmy possum & Cercartetus concinnus \\
\hline & Phocidae & Hooded seal & Cystophora cristata & & & Little pygmy possum & Cercartetus lepidus \\
\hline & & Bearded seal & Erignathus barbatus & & & Eastern pygmy possum & Cercartetus nanus \\
\hline & & Grey seal & Halichoerus grypus & & Macropodidae & Banded hare wallaby & Lagorchestes fasciatus \\
\hline & & Weddell seal & Leptonychotes weddellii & & & Western hare wallaby & Lagorchestes hirsutus \\
\hline & & Crabeater seal & Lobodon carcinophagus & & & Agile wallaby & Macropus agilis \\
\hline & & Northern elephant seal & Mirounga angustirostis & & & Black-striped wallaby & Macropus dorsalis \\
\hline & & Southern elephant seal & Mirounga leonina & & & Tammar wallaby* & Macropus eugenii \\
\hline & & Ross seal & Ommatophoca rossi & & & Eastern grey kangaroo & Macropus giganteus \\
\hline & & Harp seal & Pagophilus groenlandicus & & & Western brush wallaby & Macropus irma \\
\hline & & Ribbon seal & Phoca fasciata & & & Parma wallaby & Macropus parma \\
\hline & & Ringed seal & Phoca hispida & & & Pretty-faced wallaby & Macropus parryi \\
\hline & & Spotted seal & Phoca largha & & & Common wallaroo & Macropus robustus \\
\hline & & Baikal seal & Phoca sibirica & & & Red-necked wallaby* & Macropus rufogriseus \\
\hline & & Harbour seal & Phoca vitulina & & & Red kangaroo & Macropus rufus \\
\hline & Ursidae & Giant panda & Ailuropoda melanoleuca & & & Bridled nailtail wallaby & Onychogalea fraenata \\
\hline & & Spectacled bear & Tremarctos ornatus & & & Allied rock wallaby & Petrogale assimilis \\
\hline & & Black bear & Ursus americanus & & & Narbarlek & Petrogale concinna \\
\hline & & Brown bear & Ursus arctos & & & Black-footed rock wallaby & Petrogale lateralis \\
\hline & & Sun bear & Ursus malayanus & & & Brush-tailed rock wallaby & Petrogale pencillata \\
\hline & & Polar bear & Ursus maritimus & & & Prosperine rock wallaby & Petrogale persephone \\
\hline & & Asiatic black bear & Ursus thibetanus & & & Purple-necked rock wallaby & Petrogale purpureicollis \\
\hline & & Sloth bear & Ursus ursinus & & & Yellow-footed rock wallaby & Petrogale xanthopus \\
\hline Chiroptera & Miniopteridae & Little bent-winged bat & Miniopterus australis & & & Quokka & Setonix brachyurus \\
\hline & & Common bent-winged bat & Miniopterus schreibersii & & & Red-bellied pademelon & Thylogale billardierii \\
\hline & Pteropidae & Straw-colored fruit bat & Eidolon helvum & & & Red-necked pademelon & Thylogale thetis \\
\hline Cingulata & Dasypodidae & Southern long-nosed & Dasypus hybridus & & & Swamp wallaby & Wallabia bicolor \\
\hline & & armadillo & & & Potoroidae & Rufous bettong & Aepyprymnus rufescens \\
\hline & & Nine-banded armadillo & Dasypus novemcinctus & & & Tasmanian bettong & Bettongia gaimardi \\
\hline Eulipotyphla & Talpidae & Siberian mole & Talpa altaica & & & Burrowing bettong & Bettongia lesueur \\
\hline Pilosa & Myrmecophagidae & Giant anteater & Myrmecophaga tridactyla & & & Brush-tailed bettong & Bettongia penicillata \\
\hline & & & & & & Northern bettong & Bettongia tropica \\
\hline & & & & & & Gilbert's potoroo & Potorous gilbertii \\
\hline & & & & & & Long-nosed potoroo & Potorous tridactylus \\
\hline & & & & & Tarsipedidae & Honey possum & Tarsipes rostratus \\
\hline
\end{tabular}

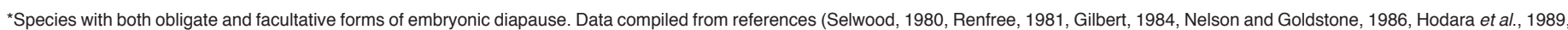

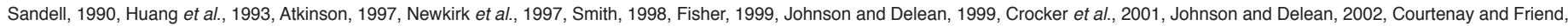
2004, Thom et al., 2004, Delean, 2007, Zhang et al., 2009, Knott et al., 2013) 
an increased understanding of the embryo-uterine dialogue has implications not only for women with recurrent miscarriages but also in improving the success rate of embryo transfers resulting from assisted reproductive technologies.

\section{Types of embryonic diapause: obligate, facultative or both}

The concepts of obligate and facultative diapause have been chronicled in the reviews that have appeared over the previous 20 years (Mead, 1993; Renfree and Shaw, 2000; Lopes et al., 2004). Obligate diapause characterizes each gestation of a species, while facultative diapause is related to some condition, usually lactational or metabolic stress that, when relieved, allows implantation to occur. Lactational diapause is common in rodent species that have a postpartum estrus and in marsupials where the ovarian cycle and inter-uterine embryo development concur in duration. Some marsupial species display a combination of the two types of diapause, where lactational delay is further extended by seasonal photoperiodic cues (Renfree and Shaw, 2000). The model species described below illustrate the similarities and differences between the facultative and obligate manifestations of diapause.

\section{Embryonic diapause in model species}

\section{Rodent facultative model}

The best studied models of diapause are the rodents, in particular the mouse and the rat. There appears to be no evidence of obligate diapause in these species, rather facultative diapause, resulting from the metabolic stress of lactation, is the most common form. The length of the delay in both mice and rats correlates with the number of offspring in the suckling litter (Pritchett-Corning et al., 2013).

Mice display estrus immediately following parturition and will then mate. The consequent embryos enter the uterus at the morula stage on the third day after mating (day $1=$ vaginal plug) and have become blastocysts by day 4 , comprised of 35 to 40 cells (Harper, 1982; McLaren, 1982). Timely achievement of this state of development requires adequate progesterone secretion from the corpus luteum (Zhang and Murphy, 2013). If metabolic stress is present, the embryo then enters diapause. Over the next 72 hours it emerges from the lysed zona pellucida and continues proliferation to approximately 130 cells, and this complement of cells persists during diapause (McLaren, 1968; Fig. 1). During diapause, the blastocysts are evenly spaced and located in uterine crypts formed from luminal closure of the uterus. Apposition of the embryos also occurs with the embryonic pole aligning with the antimesometrial epithelium but the subsequent events of implantation do not occur (Psychoyos, 1973; Nilsson, 1974). The cellular mechanisms that suspend development of the mouse embryo are not well known. An interesting hypothesis is that gene expression is attenuated by microRNA (miRNA) degradation of transcripts during diapause, preventing translation of mRNA to proteins essential to continued development. This concept is supported by the recent observation that some 38 miRNAs are more abundant in the blastocyst in diapause, relative to its activated counterpart (Liu et al., 2012). Overexpression of one of these miRNAs, Let-7a, in mouse embryos prevents implantation (Liu et al., 2012). Targets of Let-7a include several genes that regulate cell proliferation (Gurtan et al., 2013), consistent with the view that there is depletion of specific elements required for progression beyond the blastocyst stage.

In spite of markedly lower protein synthesis and carbohydrate metabolism in dormant mouse blastocysts (Weitlauf, 1974), the needs for embryo survival are met. Recent studies have revealed a potential mechanism by which the metabolic requirements are supplied to the mouse embryo during diapause (Lee et al., 2011). These authors show that dissolution of a small number of cells by autophagy allows for the recycling of vital cell nutrients in the cells of the embryo.

Reactivation of the blastocyst from diapause is very rapid in the mouse and is characterized by increases in DNA, RNA and protein synthesis, cell number and metabolism within 4-16 $\mathrm{h}$ after the resumption of development, followed closely by the initiation of implantation (Yoshinaga and Adams, 1966; Paria et al., 1993; Das et al., 1994; Spindler et al., 1996). A recent proteomic analysis, remarkable in its investigation of 6000 embryos, identified numerous factors that were differentially expressed between the diapause and activated blastocyst (Fu et al., 2014). Not unexpectedly, elements essential to aerobic glycolysis and a wide range of factors related to chromatin remodeling and proliferation were upregulated with reactivation. Glutathione metabolism, a process associated with cell protection from reactive oxygen species damage, was increased with reactivation. Further analysis of this massive database is expected to provide new insights into the process of diapause.

Early studies demonstrated that, in both mice and rats, diapause could be terminated by administration of estrone (Krehbiel, 1941).

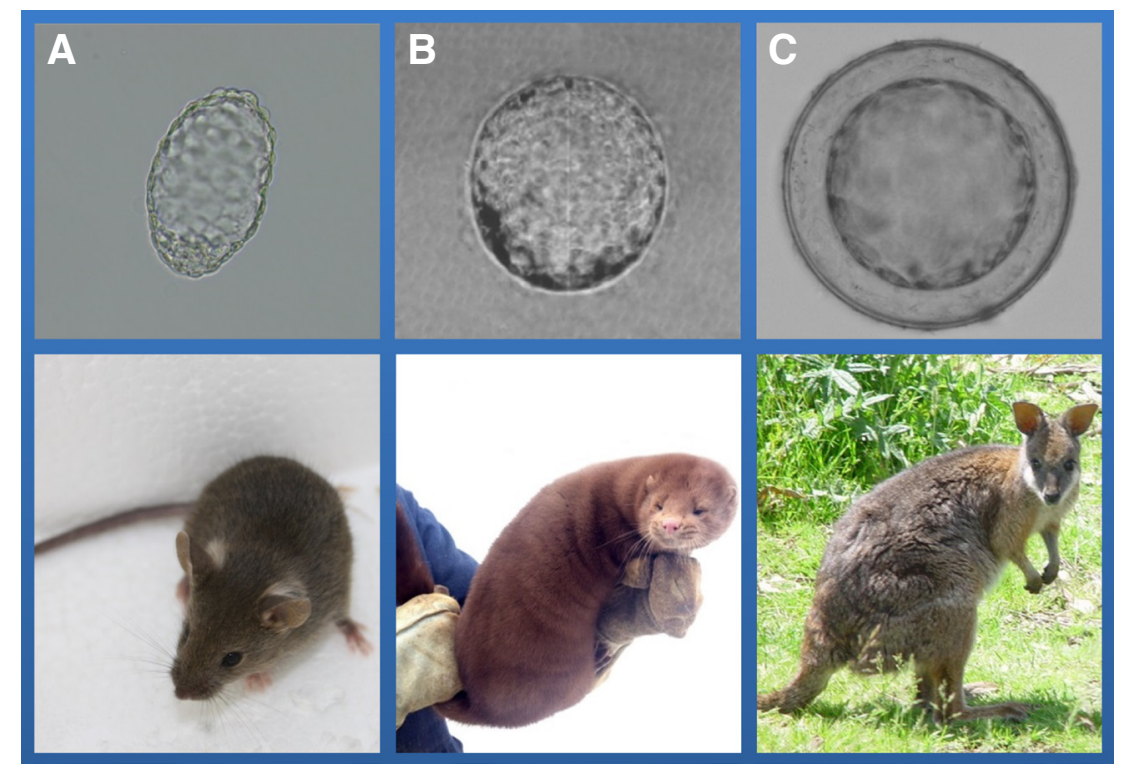

Fig. 1. Diapause embryos from the three model species. (A) Mouse blastocyst containing an inner cell mass, with the zona pellucida already shed. (B) Mink blastocyst containing an inner cell mass and surrounded by a trilaminar capsule. (C) Wallaby blastocyst with no inner cell mass, surrounded by three extracellular layers; a zona pellucida, a mucoid layer and a shell coat. 
It was later shown that an ovarian surge of estradiol secretion during late morning of the fourth day following mating is essential to induction of implantation (McCormack and Greenwald, 1974). Much of what we know about rodent implantation can be attributed to use of an experimentally induced diapause model, the ovariectomized, progesterone-treated mouse or rat, in which implantation can be predictably induced by a single administration of estrogen (Cha et al., 2013).

The ovarian compartment or cell type from whence this estrogen is secreted remains to be clarified. Furthermore, there appears to be no modern investigation of the upstream regulation of the nidatory estrogen surge in rodents. Treatment of hypophysectomized rats with luteinizing hormone (Macdonald et al., 1967) resulted in successful implantation, while passive immunization with anti-LH antiserum in early gestation prevented this event (Maneckjee and Moudgal, 1975). Beyond these observations, little is known.

The estrogen of ovarian provenance that effects implantation in the mouse uterus acts through the estrogen receptor- $\alpha$ (Esr1) and estrogen receptor- $\beta$ (Esr2). Esr1 is expressed in the uterine glands, endometrial epithelium and endometrial stroma during the period that coincides with the ovarian estrogen signal (reviewed in Vasquez and DeMayo, 2013). The role of Esr2 is less well defined, as germline deletion of the gene does not prevent implantation (Couse and Korach, 1999).

The progesterone receptors (Pgr) in the mouse uterus are essential for embryo transport prior to implantation and are clearly involved in preparation of the uterus for embryo implantation (Cha et al., 2012). The Pgr A isoform is the major functional form in the mouse uterus, and is found in the stromal, glandular and epithelial compartments of the endometrium (Vasquez and DeMayo, 2013). At the time of initiation of implantation, Pgr expression ceases to occur in the luminal and glandular epithelia, and remains only in the stroma, allowing for the estrogen-induced proliferation of the epithelium that precedes implantation (Vasquez and DeMayo, 2013). In the absence of the estrogen signal, i.e. the delay state, Pgr expression persists in the glandular and epithelial compartments, presumably contributing to embryo quiescence.

\section{Mustelid carnivore obligate model}

Obligate diapause is a widespread phenomenon among carnivores, with numerous examples in the orders Ursidae, Mephitidae, Mustelidae, Otariidae and Phocidae (Table 1). Two models have been studied in some detail, the Western spotted skunk (Spilogale gracilis) and the American mink (Neovison vison). The former species mates in the autumn with implantation and parturition occurring in late spring, with embryos in diapause for approximately 200 days (Mead, 1981). The mink, on the other hand, breeds in early to mid-March in the Northern Hemisphere, after which the embryos undergo a brief delay followed by implantation and a post-implantation gestation of 30-31 days (Murphy, 1992).

The early embryology is nearly identical between the two carnivore species, in that blastocysts develop at approximately six days after mating. During diapause in the mink, the blastocysts remain clustered in the anterior portion of the uterus with migration and spacing only occurring once reactivation has occurred. The carnivore blastocyst differs from that of the mouse in two important features, firstly, the number of cells in the embryo is substantially greater and more variable, usually reported to range from 250 to 500 cells (Fig. 1). Secondly, the embryo remains encapsulated in the zona pellucida of the oocyte which has become trilaminar, presumably due to coatings invested during the transit through the reproductive tract (Enders et al., 1986). In the skunk, there is a minor increase in the number of trophoblast cells during the lengthy period of diapause (Mead, 1981), reported to be due to endoreduplication and cell division without nuclear envelope breakdown (Isakova and Mead, 2004). A fraction of the cells of the mink embryo demonstrate DNA synthesis during diapause (Llerena-Vargas, 2011). In both species there is rapid expansion of the blastocyst and a rapid increase in both cell replication and protein synthesis associated with the reactivation of embryo development (Enders et al., 1986; Desmarais et al., 2004).

The increasing photoperiod following the vernal equinox is the proximal stimulus for the termination of dormancy and the consequent escape of the embryo from diapause in these carnivores (Murphy and James, 1974). It is mediated via the pineal gland by a decrease in the duration of the nocturnal secretion of melatonin (reviewed in Lopes et al., 2004). Increasing photoperiod translates into increased secretion of prolactin from the pituitary (Murphy, 1983), and can be prevented by dopamine agonist treatment (Papke et al., 1980), hypophysectomy (Murphy et al., 1981) and chronic melatonin treatment (Murphy et al., 1990). All three treatments abrogate implantation. Termination of diapause and precocious implantation can be induced by the administration of prolactin (Papke et al., 1980; Murphy et al., 1981). Reactivation of the embryo is first visible three days later in the form of embryo expansion, with implantation occurring around 13 days after initiation of prolactin treatment (Desmarais et al., 2004).

The corpora lutea in both the mink and skunk develop following ovulation, but cell volumes actually decline from their initial size at differentiation (Mead, 1981; Douglas et al., 1998a). Progesterone synthesis occurs, as reflected in circulating concentrations, but at a much reduced level relative to post-implantation gestation (Papke et al., 1980; Mead, 1981; Douglas et al., 1998a). Increased circulating prolactin following the equinox induces expression of both prolactin and $\mathrm{LH}$ receptors in the mink corpus luteum, and these two hypophyseal factors then drive progesterone synthesis (Murphy and Rajkumar, 1985; Douglas et al., 1998a). A peculiarity of the mink corpus luteum of diapause is that the cells are not terminally differentiated by luteinization as in other species, but retain their capacity to divide (Douglas et al., 1998b). Implantation requires secretion of an as yet unknown factor from the corpus luteum (Murphy et al., 1983). Parallel studies in the domestic ferret indicate that this factor is proteinaceous (Mead et al., 1988), a viable candidate is glucose-6-phosphate isomerase, functioning as a cytokine (Schulz and Bahr, 2003).

The endocrine maintenance of the uterine environment hospitable to the embryo in diapause and the modifications of this environment that are permissive to implantation have yet to be well explored. Multiple studies have shown that implantation is preceded by a rapid increase in circulating progesterone from the reactivated corpus luteum (Stoufflet et al., 1989; Murphy, 2012). Prolactin binds to membrane preparations from the anestrous mink uterus (Rose et al., 1983). Prolactin receptor binding to the uterus increases substantially during diapause compared to the anestrous condition, then declines following implantation (Rose et al., 1986). Analysis of prolactin receptor abundance by immunoblotting corroborates binding assay observations (Llerena-Vargas 2011). Direct effects of prolactin in the uterus of the mink remain 
to be demonstrated.

The paradigm employed successfully in the mouse, i.e. estrogen administration against a background of progesterone, does not induce implantation in the mink. Progesterone and estrogen receptor binding to the mink uterus have been explored in anestrous mink, and the results indicated that suppression of prolactin secretion increased progesterone, but not estrogen receptor populations (Slayden and Stormshak, 1992). Nuclear estrogen receptor abundance, as established by binding assays, was greater in pregnant, post-implantation mink uteri compared to the anestrous condition (Patnode and Curtis, 1994). The same authors demonstrated progesterone receptors to be present in the post-implantation uterus, but no comparisons between diapause and later gestation were made. Progesterone receptors, along with both ESR1 and ESR2 are present in the uterus of the California sea lion (Zalophus calforianus), a pinniped carnivore (Colegrove et al., 2009). Semiquantitative analysis by immunohistological staining suggests that both are substantially lower in the endometrium during diapause, relative to post-implantation gestation. No variation was evident in progesterone receptor abundance in the surface and glandular epithelium between diapause and later gestation in this species (Colegrove et al., 2009). Clearly, further investigation of steroid receptors during gestation and diapause in carnivores is warranted.

\section{Marsupial combined facultative and obligate model}

In marsupials, embryonic diapause is a common reproductive strategy, particularly amongst the Macropodidae (Table 1), where there are only three known exceptions in which it is absent, the western grey kangaroo (Macropus fuliginosus), musky rat kangaroo (Hypsiprymnodon moschatus) and Lumholtz's tree kangaroo (Dendrolagus lumholtzi) (Tyndale-Biscoe, 2005). The control of embryonic diapause in marsupials has been best studied in the tammar wallaby (Macropus eugenii), which, in contrast to the mouse and mink, is monovular and undergoes both facultative and obligate forms of embryonic diapause (reviewed in Renfree and Shaw, 2000). Facultative diapause in the wallaby occurs after mating at the postpartum estrus, and is induced by the suckling stimulus of the newborn young in the pouch. Tammar wallabies give birth to single, precocious young in late January in the southern hemisphere, which then completes its development in the pouch, emerging around late September. Mating occurs following parturition, and, if the pouch young is lost before May, the single embryo in diapause will reactivate and be born around 27 days later. If however the pouch young is lost after this time, the embryo will remain in a seasonally-induced obligate diapause until late December (after the summer solstice). Thus, the wallaby embryo can remain in diapause for as long as eleven months.

The wallaby blastocyst forms after 6 days and, in contrast to Eutherian species, is a unilaminar structure of around 80 cells with no inner cell mass, and with no sign of an embryonic disc appearing until around day 9 after reactivation (Fig. 1; Renfree, 1994; Frankenberg et al., 2013). Similar to the carnivores, the wallaby blastocyst remains enclosed in its zona pellucida during diapause but there are also an additional two layers, a mucin layer and a shell coat, both laid down during passage through the reproductive tract (Fig. 1). During diapause, the single blastocyst remains free floating in the uterus with no observable mitosis or cell growth, but it maintains a basal metabolism and low levels of
RNA and protein synthesis (Moore, 1978; Tyndale-Biscoe, 1978; Thornber et al., 1981; Shaw and Renfree, 1986; Tyndale-Biscoe and Renfree;1987, Spindler et al., 1998; Spindler et al., 1999a). Reactivation of the blastocyst from diapause is characterized by a resumption of the cell cycle and increased metabolism.

Although tammar wallabies undergo both facultative and obligate diapause, endocrine cues regulating either version result in inhibition of the immature corpus luteum by prolactin secreted from the pituitary (Hinds, 1989; Hinds and Tyndale-Biscoe, 2013). During facultative diapause, the suckling of the pouch young sends a neural signal to the hypothalamus, whilst during obligate diapause, photoperiodic signals are transduced by melatonin secretion from the pineal gland (Renfree, 1979; Tyndale-Biscoe et al., 1986). Reactivation from embryonic diapause in the wallaby requires removal of the prolactin-induced inhibition of the corpus luteum for a minimum of three days by either removal of the pouch young or by a decreased photoperiod accompanied by a change in the length of the daily episode of melatonin secretion (Hinds and Tyndale-Biscoe, 1982; Hinds et al., 1983; Shaw and Renfree, 1984; Hinds, 1989). Diapause can be experimentally terminated in the wallaby by hypophysectomy or by treatment with either the dopamine agonist, bromocriptine during lactational quiescence, or by melatonin during seasonal quiescence (Hearn, 1974; Tyndale-Biscoe and Hinds, 1984; 1992). Nonetheless, quiescent wallaby blastocysts are not reactivated by bilateral ovariectomy (Tyndale-Biscoe and Hearn, 1981). Reactivation from diapause occurs slowly in the wallaby with the first signs that the blastocyst has reactivated at day 4, followed by embryo expansion at day 8 , with shell coat rupture and attachment to the uterine wall occurring around 18 days after reactivation (Renfree and Tyndale-Biscoe, 1973; Denker and Tyndale-Biscoe, 1986; Shaw and Renfree, 1986; Spindler et al., 1998; Spindler et al., 1999b).

At entry into diapause, the corpus luteum is still maturing, and progesterone levels are basal (Tyndale-Biscoe and Renfree, 1987). Prolactin secreted daily from the pituitary prevents the preimplantation progesterone pulse from occurring (Hearn, 1974; Tyndale-Biscoe and Renfree, 1987; Hinds, 1989). During diapause, high concentrations of prolactin receptors are present in the corpus luteum, levels of which halve at reactivation (Stewart and Tyndale-Biscoe, 1982). Nonetheless, prolactin does not have a luteotrophic role in the corpus luteum in marsupials and there is no evidence for luteinizing hormone binding to this tissue (Stewart and Tyndale-Biscoe, 1982; Bradshaw and Bradshaw, 2011). Removal of the prolactin inhibition is then followed by a pulse of progesterone around day 5 of reactivation. Both ESR and PGR are expressed in the wallaby endometrium at high concentrations during both diapause and early reactivation, but both decrease to relatively low levels after the pulse of progesterone (Renfree and Blanden, 2000). Both ESR1 and ESR2 isoforms exist in the tammar, but it is unknown whether there are any differences in their expression in the endometrium. Although both estradiol and progesterone can initiate reactivation in the wallaby, it can only be maintained by progesterone (Renfree and Tyndale-Biscoe, 1973; Fletcher et al., 1988).

Thus in the three model species, the sequence of endocrine events leading to diapause and reactivation are well defined, albeit variant. Although there are multiple mechanisms involved in diapause across mammals, all appear to exert their effects on the uterine environment. However, it is unclear how the uterine 
environment acts on the blastocyst to control diapause or whether this process is conserved across species.

\section{Commonalities in embryo implantation}

Numerous elements of the initial implantation process appear conserved among mammals. The notion of a temporal period of uterine receptivity, known as the window of implantation, was established by asynchronous transfers of embryos into the uteri of females in various stages of pseudopregnancy (Psychoyos, 1986). The concept has proven valid in virtually all species studied (Yoshinaga, 1988). Among the constants for receptivity across species is the presence of luteal progesterone, and, in many species, ovarian or locally synthesized estrogens (Zhang et al., 2013). Consistent with this, reactivation from diapause also requires the presence of steroid hormones and a lack of uterine receptivity has been suggested to be a factor in the induction of embryonic diapause (Paria et al., 1993). A second generality of receptivity is that it engenders alteration of anti-adhesive elements, principally glycoproteins found on the endometrial epithelial surface, that have the capacity to inhibit implantation (Bazer et al., 2010). Attachment of the trophoblast to the extracellular matrix of the endometrial epithelium is a progressive process, first involving carbohydrate ligand binding, then employing factors that include the selectins, trophonin and heparin-binding epidermal growth factor (HBEGF) (Fukuda and Sugihara, 2008).

The dialogue between the embryo and uterus, to date only partially understood, is an essential element of both embryonic diapause and the implantation process in mammals. In polytocous species, embryos become spaced along the uterine horn. It is hypothesized that the mouse embryo secretes factors, perhaps proteins of the wingless (Wnt) family that activate Wnt signaling in the uterus with effects on the myometrium, that may then, in turn, affect the spacing of the embryos (Mohamed et al., 2005). Targeted deletion of cytosolic phospholipase-A2 $\alpha$ disrupts embryo spacing, indicating that lipid signaling plays a role in this process (Song et al., 2002).

There appear to be other common factors of uterine provenance essential for implantation across species, in particular, the cytokines such as interleukin-1 $\beta$ (IL1b)(Bourdiec et al., 2013), leukemia inhibitory factor (LIF), and growth factors including bone morphogenic protein-2 (BMP2), fibroblast growth factors (FGF) and HBEGF, among others (Cha et al., 2012). In the mouse, the binding of endometrial Hbegf to its receptor, Erbb4 on the blastocyst, coordinates the initiation of implantation, a mechanism consistent with observations in humans (Yoo et al., 1997; Leach et al., 1999; Chobotova et al., 2002). Further candidates are the signaling molecules of the WNT family (Chen et al., 2009; van der Horst et al., 2012). The muscle segment homeobox-1 (Msx1) is essential for uterine receptivity in the mouse (Daikoku et al., 2011). Msx1 is an upstream regulator of the Wnt genes and its targeted disruption in the uterus disrupts Wnt signaling patterns, altering the state of the uterine epithelium in the mouse (Nallasamy et al., 2012). Uterine polyamines also appear to be essential, at least in carnivore and rodent species (Lefevre et al., 2011c).

Knowledge of embryonic signals in the implantation process is sparse, prostaglandins of the E-series are candidates (Lopes et al., 2007). However, many of the above factors are also present in the blastocyst. Currently, limited evidence is available confirming which of the factors active during implantation are involved in the control of embryonic diapause. A more profound understanding of embryo-uterine communication is key to elaboration of the mechanisms of embryonic diapause.

\section{The uterus dictates diapause}

In the mouse, reactivation of the uterus after diapause is regulated by ovarian steroid hormones, and the induction of a favorable uterine environment is required for subsequent development of the blastocyst (Paria et al., 1993). However, the in vitro addition of steroid hormones directly to mouse embryos in diapause does not result in their reactivation (Weitlauf, 1974).

Embryo transfers of blastocysts to delay-state uteri in rodents (Weitlauf and Greenwald, 1968) and reciprocal transfer of embryos from a species displaying obligate diapause, the mink, to a species without evidence of diapause, the domestic ferret (Chang, 1968) have defined the uterus as the regulator of developmental arrest. Similarly, mink blastocysts in diapause resumed development when co-cultured with conspecific uterine cell lines, and wallaby blastocysts in diapause are able to reactivate and develop normally when transferred to a reactivated uterus (Tyndale-Biscoe, 1970; Moreau et al., 1995). Wallaby blastocysts displaying delay in their metabolic reactivation were found to be from mothers with a low endometrial metabolism, indicating a failure of the maternal system to reactivate (Spindler et al., 1998). Since both the wallaby and mink blastocyst are surrounded by multiple acellular layers and do not implant until a number of days after reactivation, factors controlling diapause must reach the embryo via the uterine secretions (Renfree, 1973; Shaw and Renfree, 1986; Renfree and Shaw, 2000).

The notion of uterine regulation of diapause is further strengthened by the remarkable recent findings that the sheep blastocyst can be induced to undergo developmental arrest if transferred to the uteri of pseudopregnant mice, and can then, if transplanted back to the uterus of the ewe, produce normal lambs (Ptak et al., 2012).

As noted above, numerous factors secreted by the uterus that are essential to the implantation process are common to multiple species, and their expression, or lack thereof, is expected to be a mechanism by which the uterus dictates diapause. The first sign of reactivation from diapause in the mouse is the detection of Hbegf in the endometrium, 6-7 hr before implantation commences but only adjacent to the blastocyst, (Das et al., 1994). We recently showed that Msx1 or Msx2, transcriptional regulators of some uterine implantation factors, persist in the uterus across three species of widely differing taxa, mice, mink and wallabies, during embryonic diapause (Cha et al., 2013). Together, the observation of uterine control and conserved regulation indicates common mechanisms were established during the evolution of diapause. Furthermore, the findings of Ptak et al., (2012) in the sheep suggest that the potential for diapause is not restricted to the species where it is known to occur.

The mechanisms by which the uterus induces and maintains developmental arrest remain to be established. Some evidence points to an inhibitory effect of the uterine environment that inhibits embryo development during diapause. Incubation of rabbit blastocysts with the protein fraction of flushings from the mouse uterus in the diapause state inhibits embryonic DNA synthesis (Weitlauf, 1978). In the mouse, levels of the endocannabinoid, anandamide 
appear to play a significant role in regulating reactivation of the blastocyst from embryonic diapause (Wang et al., 2003). Whilsthigh levels of anandamide maintain diapause, low levels can activate the blastocyst. In addition, anandamide binds to the cannabinoid receptors, $\mathrm{CB} 1$ and $\mathrm{CB} 2$. The levels of $\mathrm{CB} 1$ are up-regulated in the blastocyst trophectoderm during diapause and rapidly downregulated at reactivation (Wang et al., 2003). Hence, high levels of anandamide may act as an inhibitory factor in the mouse. Although the mouse embryo is able to reactivate its metabolism in vitro, it is not "implantation competent" (Weitlauf, 1974; Paria et al., 1993; Spindler et al., 1998; Spindler et al., 1999a). Furthermore, incubation of mouse blastocysts with wallaby uterine exudates collected during diapause did not completely cause the mouse embryo to enter into diapause and did not maintain diapause in vitro (Spindler et al., 1999a).

The contrasting view is that during diapause, the uterine factors essential for continued embryogenesis are lacking, thus resulting in a developmental arrest. Although the uterus of the mouse has fewer endometrial glands than found in the other model species, the glands are active in secretion during the peri-implantation period (Given and Enders, 1980). Termination of experimental diapause in the mouse by estrogen treatment induces changes that parallel those seen during implantation (Given and Enders 1978), suggesting glandular secretions essential to implantation are not present during diapause. In the wallaby during diapause, uterine secretions are low and the uterus remains quiescent (Renfree, 1973; Shaw and Renfree, 1986; Tyndale-Biscoe and Renfree, 1987; Spindler et al., 1998). Furthermore, dormant blastocysts from both the wallaby and the mink do not reactivate when cultured in vitro (Moreau et al., 1995; Renfree and Shaw, 2000). One potential candidate for a missing factor is LIF, which is essential for embryonic stem cell proliferation (Zhao et al., 2012) and for implantation in the mouse (Hondo and Stewart, 2005). LIF expression in the uterine epithelium and glands appears at the termination of diapause in the mouse, mink and the wallaby (Bhatt et al., 1991; Stewart et al., 1992; Song et al., 1998; Renfree, personal communication). In the mouse, LIF expression appears to be under estrogenic control and can replace the estrogen injection to induce reactivation (Chen et al., 2000).

However, it is unlikely that reactivation from embryonic diapause is the result of one particular signal, but a combination of a range of factors, each with a specific downstream function. Among the best recent candidates for uterine factors that are required to terminate diapause are the polyamines, known to be involved in diverse reproductive functions in mammals (Lefevre et al., 2011c). Polyamine synthesis is rate limited by the ornithine decarboxylase-1 (ODC1) enzyme (Lefevre et al., 2011c). As noted above, an episode of ovarian estrogen secretion is the key event in termination of mouse diapause. It has been shown that there is an increase in the expression of not only Odc1, but also other genes that modulate polyamine availability, Sat1, Samdc, Sms and Smox, at the time of estrogen-induced reactivation of the mouse blastocyst (Zhao et al., 2008). Implantation sites in the mouse display elevated levels of expression of Odc1 and polyamines (Zhao et al., 2008). Blockade of Odc1 conversion of ornithine to the polyamine putrescine by the suicide inhibitor difluoromethylornithine (DFMO) prevents implantation in the mouse (Zhao et al., 2008) and reversibly arrests development in mink (Lefevre et al., 2011b) and mouse (Zwierzchowski et al., 1986) embryos. Expression of ODC1, along with the polyamine availability genes (Lefevre et al., 2011a) and uterine content of the polyamine putrescine (Lefevre et al., 2011b), are upregulated at the termination of diapause in the mink (Murphy, 2012).

Although polyamines have pleiotropic actions in cellular systems, few molecular targets have been defined (Zhao et al., 2012). The mechanisms by which their absence or paucity induces or maintains diapause remain to be determined, but, given the developmental arrest of diapause, regulation of cell proliferation is an obvious candidate. Polyamines act as supercations at physiological $\mathrm{pH}$, thus interacting with polyanions in the cell, including nucleic acids, proteins and phospholipids (Wallace et al., 2003). Polyamines stabilize DNA structure and promote chromatin remodeling and transcription (Wallace et al., 2003). Polyamine synthesis is associated with the cell cycle, with synthetic peaks at the G1-S transition and during the S-phase of the cycle (Alm and Oredsson, 2009). In neuroblastoma cells, inhibition of polyamine synthesis leads to accumulation of the cell cycle inhibitors and arrest of the cell cycle in the G0/G1 phase (Koomoa et al., 2013). The evidence, albeit limited, indicates that diapause, at least in the mouse, is also due to arrest prior to the S-phase of the cell cycle (reviewed in Lopes et al., 2004). Microarray analysis comparing dormant with reactivated mouse embryos showed increased expression of cell cycle inhibitory factor genes in the diapause condition (Hamatani et al., 2004). An attractive, if simplistic hypothesis is that, in the absence of polymines, the cells of the diapause embryo remain in a state of interphase.

\section{The embryo plays a proactive role in its own development}

Although it appears that uterine factors control the events of embryonic diapause, the blastocyst itself also has a role in determining its own development. In many eutherian species, embryo signaling ensures maternal recognition of pregnancy by maintaining a functional corpus luteum, although the factor involved can differ, depending on the species (reviewed in Bazer et al., 2010). In the mouse uterus at decidualization, approximately $10 \%$ of all genes expressed in the endometrium are differently expressed in the presence of an embryo (Kashiwagi et al., 2007). Studies have demonstrated pinocytic activity in the rat uterus at the time of implantation, indicating uptake of substances from the lumen (Enders and Nelson 1973), and providing a mechanism for transfer of embryonic signals to the endometrium. The level of pinocytosis, as determined by morphological methods, is lower when the embryos are in diapause (Enders and Nelson 1973). It is not clear whether the material taken up is of embryonic provenance, but this observation, along with the information cited above suggests that the embryo takes a proactive role in preparing the maternal environment to support its own development. Mouse embryos can survive in simple, defined media, indicating a certain autonomy from the uterine environment, because they are believed capable of producing autocrine factors to enhance their own development (Whitten, 1957). It is therefore possible that, during diapause, the absence of paracrine signaling from the uterus down-regulates this autocrine production by the embryo.

In the mouse there are over 200 genes differentially expressed between the dormant and activated blastocyst, 149 of which are upregulated at reactivation (Hamatani et al., 2004). One of these, Hbegf, is the only ligand significantly upregulated in the blastocyst at reactivation, and is able to induce its own expression in the en- 
dometrium (Hamatani et al., 2004). It would therefore appear that the embryo can function as an active unit with its own molecular program of cell growth and differentiation (Paria et al., 2002; Dey et al., 2004; Dey and Lim, 2006).

\section{Diapause: a common mechanism or convergent evolu- tion?}

Given that we were not present during the evolutionary trajectory that resulted in the establishment of the reproductive mechanisms of extant species, suppositions on the evolution of diapause cannot be confirmed. Two divergent views can be considered (Table 2). It has been theorized by Sandell (1990) that diapause evolved independently multiple times, in both its facultative and obligate manifestations. This conclusion is based primarily on the occurrence or non-occurrence of diapause in congeneric species such as the ermine (Mustela ermina) and long-tailed weasel (Mustela frenata), both diapause species, and the least weasel (Mustela nivalis), a species that displays no diapause. A classic example is the spotted skunk, where the western species (Spilogale gracilis) displays obligate diapause and its eastern counterpart, (Spilogale putorius), does not (Mead, 1993). A second argument for convergent evolution is that the trait is found in a wide variety of species, including armadillos, at least one mole, three species of bats and an ungulate, the roe deer (Table 1) that have a wide divergence of placentation, post-implantation embryogenesis and other reproductive strategies. As can be seen in the model species, the diversity of regulatory mechanisms further argues for independent evolution of diapause. Prolactin can maintain diapause (marsupials), terminate diapause (mustelids) or have no effect (rodents). The ovaries are essential for implantation in the model species, but, remarkably, in the nine-banded armadillo (Dasypus novemcinctus), implantation of blastocysts in diapause is induced by ovariectomy, occurring 1829 days after removal of the ovaries in the absence of exogenous hormone treatment (Buchanan et al., 1956).

There is evidence for the contrary view, i.e. that diapause evolved but a few times, or even only once, and that control mechanisms have evolved to exploit the trait when it provides reproductive advantage to the species. The facultative condition argues for this possibility, in that an embryo can undergo diapause or not, depending on metabolic stress on the dam. In the absence of a pouch young, the wallaby embryo will not undergo diapause and its gestation length is shortened as a result (reviewed in TyndaleBiscoe and Renfree, 1987). This concept is further supported in

\section{TABLE 2}

\section{THE ORIGIN OF DIAPAUSE, CONVERGENT EVOLUTION vs. A SINGLE EVOLUTIONARY EVENT}

\begin{tabular}{ll} 
Diapause evolved once & Diapause evolved multiple times \\
\hline $\begin{array}{l}\text { Facultative diapause-dormancy can be } \\
\text { induced }\end{array}$ & $\begin{array}{l}\text { Diapause is present in a wide variety of species } \\
\text { with greatly differing implantation processes } \\
\text { and placentation } \\
\text { Wide variety of endocrine regulatory } \\
\text { mechanisms } \\
\text { Presence/absence in congeneric species }\end{array}$ \\
$\begin{array}{l}\text { Induction of diapause in non-diapause } \\
\text { species by transfer of embryos to the delay in embryonic characteristics of } \\
\text { diapause among species }\end{array}$ \\
$\begin{array}{l}\text { Commonality of uterine regulatory } \\
\text { mechanisms }\end{array}$ \\
\begin{tabular}{l} 
Always occurs at the blastocyst stage \\
\hline
\end{tabular}
\end{tabular}

the context of obligate diapause, in that development was arrested at the blastocyst stage in ferret, a non-diapause species, when these embryos were transplanted to the uterus of the mink (Chang, 1968). Furthermore, delay in implantation was induced in ferrets by manipulation of the ovarian hormonal milieu (Foresman and Mead, 1978).

The work of Ptak and colleagues (2012), whereby they successfully induced diapause in sheep embryos by placing them in the uterus of a mouse has provided a new perspective on the question. The same laboratory has apparently repeated the finding using two other non-diapause species, the cow and the rabbit (alluded to but unpublished by Ptak et al., 2013). These experiments indicate that embryos of non-diapause species can survive in the blastocyst state for an extended period of time, and be reactivated in a pattern similar to that seen at termination of delayed implantation in the mouse. The experimental paradigm of Ptak (2012) provides for the possibility of an in depth exploration of the embryo-uterine dialogue that will shed further light on the evolution of diapause.

\section{Pressing questions}

While progress has been made in the understanding of embryonic diapause in recent years, a number of issues remain to be more satisfactorily resolved. The embryo-uterine dialogue that first suspends development and then allows it to recommence, requires further exploration. In particular it would be valuable to confirm whether the uterus directly inhibits development during diapause, or whether the arrest in development is due to deprivation of factors necessary for further embryogenesis. We know little about the mechanisms of suspension of the cell cycle or about the strategy employed by the embryo to survive at the very low metabolic rate of diapause. It is hoped that the rapidly evolving cell and molecular biology technology will provide the tools to answers these and other questions pertinent to diapause.

\section{Acknowledgements}

Research on diapause from the laboratory of B.D. Murphy was made possible by the generous and consistent support of the Natural Sciences and Engineering Research Council of Canada. Jane Fenelon and Arnab Banerjee were recipients of postdoctoral fellowships from the Canadian Institutes of Health Research. We thank Drs. Kalyne Bertolin and Marilyn Renfree for the photos in Figure 1.

\section{References}

ALM, K. and S. OREDSSON (2009). Cells and polyamines do it cyclically. Essays Biochem 46: 63-76.

ATKINSON, S (1997). Reproductive biology of seals. Rev Reprod 2: 175-194.

BAZER, F. W., G. WU, T. E. SPENCER, G. A. JOHNSON, R. C. BURGHARDT and K. BAYLESS (2010). Novel pathways for implantation and establishment and maintenance of pregnancy in mammals. Molec Hum Reprod 16: 135-152.

BHATT, H., L. J. BRUNET and C. L. STEWART (1991). Uterine expression of leukemia inhibitory factor coincides with the onset of blastocyst implantation. Proc Natl Acad Sci USA 88: 11408-11412.

BOURDIEC, A., E. CALVO, C. V. RAO and A. AKOUM (2013). Transcriptome analysis reveals new insights into the modulation of endometrial stromal cell receptive phenotype by embryo-derived signals interleukin-1 and human chorionic gonadotropin: possible involvement in early embryo implantation. PloS One 8:e64829.

BRADSHAW, F. J. and D. BRADSHAW (2011). Progesterone and reproduction in marsupials: A review. Gen Comp Endocrinol 170: 18-40.

BUCHANAN, G. D., A. C. ENDERS and R. V. TALMAGE (1956). Implantation in 
armadillos ovariectomized during the period of delayed implantation. J Endocrinol 14: 121-128.

CHA, J., X. SUN, A. BARTOS, J. FENELON, P. LEFEVRE, T. DAIKOKU, G. SHAW, R. MAXSON, B. D. MURPHY, M. B. RENFREE and S. K. DEY (2013). A new role for muscle segment homeobox genes in mammalian embryonic diapause. Open Biology 3: 130035.

CHA, J., X. SUN and S. K. DEY (2012). Mechanisms of implantation: strategies for successful pregnancy. Nat Med 18: 1754-1767.

CHANG, M. C (1968). Reciprocal insemination and egg transfer between ferrets and mink. J Exp Zool 168: 49-60.

CHEN, J. R., J. G. CHENG, T. SHATZER, L. SEWELL, L. HERNANDEZ and C. L. STEWART (2000). Leukemia inhibitory factor can substitute for nidatory estrogen and is essential to inducing a receptive uterus for implantation but is not essential for subsequent embryogenesis. Endocrinology 141: 4365-4372.

CHEN, Q., Y. ZHANG, J. LU, Q. WANG, S. WANG, Y. CAO, H. WANG, and E. DUAN (2009). Embryo-uterine cross-talk during implantation: the role of Wnt signaling. Molec Hum Reprod 15: 215-221.

CHOBOTOVA, K., I. SPYROPOULOU, J. CARVER, S. MANEK, J. K. HEATH, W. J. GUILLICK, D. H. BARLOW, I. L. SARGENT and H. J. MARDON (2002). Heparinbinding epidermal growth factor and its receptor ErbB4 mediate implantation of the human blastocyst. Mech Dev 119: 137-144.

COLEGROVE, K. M., F. M. GULLAND, D. K. NAYDAN and L. J. LOWENSTINE (2009). The normal genital tract of the female California sea lion (Zalophus californianus): cyclic changes in histomorphology and hormone receptor distribution. Anat Rec 292: 1801-1817.

COURTENAY, J. and T. FRIEND (2004). Gilbert's potoroo (Potorous gilbertii) recovery plan July 2003-June 2008. In Western Australian Wildlife Management Program No.32. Western Australian Threatened species and communities unit, Wanneroo, Western Australia.

COUSE, J. F. and K. S. KORACH (1999). Estrogen receptor null mice: what have we learned and where will they lead us? Endocr Rev 20: 358-417.

CROCKER, D. E., J. D. WILLIAMS, D. P. COSTA and B. J. L. BOEUF (2001). Materna traits and reproductive effort in northern elephant seals. Ecology 82: 3541-3555.

DAIKOKU, T., J. CHA, X. SUN, S. TRANGUCH, H. XIE, T. FUJITA, Y. HIROTA, J. LYDON, F. DEMAYO, R. MAXSON and S. K. DEY (2011). Conditional deletion of Msx homeobox genes in the uterus inhibits blastocyst implantation by altering uterine receptivity. Dev Cell 21: 1014-1025

DAS, S. K., X.-N. WANG, B. C. PARIA, D. DAMM, J. A. ABRAHAM, M. KLAGSBRUN, G. K. ANDREWS and S. K. DEY (1994). Heparin-binding EGF-like growth factor gene is induced in the mouse uterus temporally by the blastocyst solely at the site of apposition: a possible ligand for interaction with blastocyst EGF-receptor in implantation. Development 120: 1071-1083.

DELEAN, S. C (2007). Longitudinal population demography of the allied rock-wallaby, Petrogale assimilis. Page 341. In School of Earth and Environmental Sciences. Vol. Doctor of Philosophy. James Cook University.

DENKER, H.-W. and C. H. TYNDALE-BISCOE (1986). Embryo implantation and proteinase activities in a marsupial (Macropus eugenii). Cell Tissue Res 246:279-291.

DESMARAIS, J. A., V. BORDIGNON, F. L. LOPES, L. C. SMITH and B. D. MURPHY (2004). The escape of the mink embryo from obligate diapause. Biol Reprod 70: $662-670$.

DEY, S. K. and H. LIM (2006). Implantation. Pages 147-188 in Knobil and Neill's Physiology of Reproduction. Vol. 1. Third Edition ed. J. D. Neill, ed. Elsevier.

DEY, S. K., H. LIM, S. K. DAS, J. REESE, B. C. PARIA, T. DAIKOKU and H. WANG (2004). Molecular cues to implantation. Endocr Rev 25: 341-373.

DOUGLAS, D. A., A. HOUDE, J. H. SONG, R. FAROOKHI, P. W. CONCANNON and B. D. MURPHY (1998a). Luteotropic hormone receptors in the ovary of the mink (Mustela vison) during delayed implantation and early-postimplantation gestation. Biol Reprod 59: 571-578

DOUGLAS, D. A., J. H. SONG, G. M. MOREAU and B. D. MURPHY (1998b). Differentiation of the corpus luteum of the mink (Mustela vison): mitogenic and steroidogenic potential of luteal cells from embryonic diapause and postimplantation gestation. Biol Reprod 58: 1163-1169.

ENDERS, A.C. and D.M. NELSON (1973). Pinocytotic activity of the uterus of the rat. Am J Anat 138: 277-300.

ENDERS, A. C., S. SCHLAFKE, N. E. HUBBARD and R. A. MEAD (1986). Morphological changes in the blastocyst of the western spotted skunk during activation from delayed implantation. Biol Reprod 34: 423-437

FISHER, D. O (1999). Offspring sex ratio variation in the bridled nailtail wallaby, Onychogalea fraenata. Behav Ecol Sociolbiol 45: 411-419.

FLETCHER, T. P., A. E. JETTON and M. B. RENFREE (1988). Influence of progesterone and oestradiol-17 $\beta$ on blastocysts of the tammar wallaby (Macropus eugenii) during seasonal diapause. J Reprod Fert 83: 193-200.

FORESMAN, K. R. and R. A. MEAD (1978). Luteal control of nidation in the ferret (Mustela putorius). Biol Reprod 18: 490-496.

FRANKENBERG, S., G. SHAW, C. FREYER, A. J. PASK and M. B. RENFREE (2013). Early cell lineage specification in a marsupial: a case for diverse mechanisms among mammals. Development 140: 965-975.

FU, Z., WANG, B., WANG, S., WU, W., WANG, Q., CHEN, Y., KONG, S., LU, J. TANG, Z., DUAN, E., WANG, H., WANG, Y., LI, L., WANG, F., GAO, S., and WANG, H. (2014). Integral proteomic analyis of blastocyst reveals key molecular machinery governing embryonic diapause and reactivation for implantation in mice. Biol Reprod 90: 1-11.

FUKUDA, M. N. and K. SUGIHARA (2008). An integrated view of L-selectin and trophinin function in human embryo implantation. J Obst Gyn Res 34: 129-136.

GILBERT, A. N (1984). Postpartum and lactational estrus: a comparative analysis in rodentia. J Comp Psych 98: 232-245.

GIVEN, R.I. and ENDERS, A.C (1978). Mouse uterine glands during the delayed and induced implantation periods. Anat Rec 290: 271-283.

GIVEN, R.I. and ENDERS, A.C (1980). Mouse uterine glands during the periimplantation period: Fine structure. Am J Anat 157: 169-179.

GURTAN, A. M., A. RAVI, P. B. RAHL, A. D. BOSSON, C. K. JNBAPTISTE, A BHUTKAR, C. A. WHITTAKER, R. A. YOUNG and P. A. SHARP (2013). Let-7 represses Nr6a1 and a mid-gestation developmental program in adult fibroblasts. Genes Dev 27: 941-954.

HAMATANI, T., T. DAIKOKU, H. WANG, H. MATSUMOTO, M. G. CARTER, M. S. KO and S. K. DEY (2004). Global gene expression analysis identifies molecular pathways distinguishing blastocyst dormancy and activation Proc Natl Acad Sci USA 101: 10326-10331.

HARPER, M. J. K (1982). Sperm and egg transport. in Germ cells and fertilisation. Vol. 1. 2nd ed. C. R. Austin and R. V. Short, ed. Cambridge University Press, Cambridge. pp. 102-107

HEARN, J. P (1974). The pituitary gland and implantation in the tammar wallaby, Macropus eugenii. J Reprod Fert 39: 235-241.

HEIDEMAN, P. D (1989). Delayed development in Fischer's pygmy fruit bat, Haplonycteris fischeri, in the Philippines. J Reprod Fert 85: 363-382.

HINDS, L. A (1989). Morning pulse of prolactin maintains seasonal quiescence in the tammar, Macropus eugenii. J Reprod Fert 87: 735-744.

HINDS, L. A., S. M. EVANS and C. H. TYNDALE-BISCOE (1983). In-vitro secretion of progesterone by the corpus luteum of the tammar wallaby, Macropus eugenii. J Reprod Fert 67: 57-63.

HINDS, L. A. and C. H. TYNDALE-BISCOE (1982). Plasma progesterone levels in the pregnant and non-pregnant tammar, Macropus eugenii. J Endocrinol 93: 99-107.

HINDS, L. A. and C. H. TYNDALE-BISCOE (2013). Daily prolactin pulse inhibits the corpus luteum during lactational quiescence in the marsupial, Macropus eugenii. Reprod Fert Dev 25: 456-461.

HODARA, V. L., M. B. ESPINOSA, M. S. MERANI and C. QUINTANS (1989). Calomys laucha (Rodentia, Cricetidae): growth and breeding in laboratory conditions. Lab Anim 23: 340-344.

HONDO, E. and C. L. STEWART (2005). Profiling gene expression in growth-arrested mouse embryos in diapause. Genome Biol 6: 202

HUANG, J. L., M. POWELL and R. A. MEAD (1993). Luteal protein secretion during preimplantation in the ferret. Biol Reprod 48: 647-654.

HUNTER, R. H. F (1995). Sex determination, differentiation and intersexuaity in placental mammals. Press Syndicate of the University of Cambridge Cambridge United Kingdom.

ISAKOVA, G. K. and R. A. MEAD (2004). Occurrence of amitotic division of trophoblast cell nuclei in blastocysts of the western spotted skunk (Spilogale putorius latifrons). Hereditas 140: 177-184

JOHNSON, P. M. and S. C. DELEAN (1999). Reproduction in the Prosperine rockwallaby, Petrogale persephone Maynes (Marsupialia: Macropodidae), in captivity, with age estimation and development of pouch young. Wildlife Res 26: 631-639. 
JOHNSON, P. M. and S. C. DELEAN (2002). Reproduction of the purple-necked rock-wallaby, Petrogale purpureicollis Le Souef (Marsupialia: Macropodidae) in captivity, with age estimation and development of the pouch young. Wildlife Research 29: 463-468.

KASHIWAGI, A., C. M. DIGIROLAMO, Y. KANDA, Y. NIIKURA, C. T. ESMON, T. R. HANSEN, T. SHIODA and J. K. PRU (2007). The postimplantation embryo differentially regulates endometrial gene expression and decidualization. Endocrinology 148: 4173-4184.

KNOTT, K. K., B. M. ROBERTS, M. A. MALY, C. K. VANCE, J. DEBEACHAUMP, J. MAJORS, P. RIGER, H. DECALUWE and A. J. KOUBA (2013). Fecal estrogen, progestagen and glucocorticoid metabolites during the estrous cycle and pregnancy in the giant anteater (Myrmecophaga tridactyla): evidence for delayed implantation. Reprod Biol and Endocrinol 11: 83

KOOMOA, D. L., D. GEERTS, I. LANGE, J. KOSTER, A. E. PEGG, D. J. FEITH and A. S. BACHMANN (2013). DFMO/eflornithine inhibits migration and invasion downstream of MYCN and involves p27Kip1 activity in neuroblastoma. Int $J$ Oncol 42: 1219-1228.

KREHBIEL, R. H(1941). The effects of theelin on delayed implantation in the pregnant lactating rat.. Am J Anat 81: 381-392.

LATASTE, F (1891). Des variations de durée de la gestation chez les mammifères et des circonstances qui déterminent ces variations, $C R$ Soc Biol 43: 21-31.

LEACH, R. E., R. KHALIFA, N. D. RAMIREZ, S. K. DAS, J. WANG, S. K. DEY, R. ROMERO and D. R. ARMANT (1999). Multiple roles for heparin-binding epidermal growth factor-like growth factor are suggested by its cell-specific expression during the human endometrial cycle and early placentation. J Clin Endocrinol Metab 84: 3355-3363.

LEE, J. E., H. A. OH, H. SONG, J. H. JUN, C. R. ROH, H. XIE, S. K. DEY and H. J. LIM (2011). Autophagy regulates embryonic survival during delayed implantation. Endocrinology 152: 2067-2075.

LEFEVRE, P. L., M. F. PALIN, D. BEAUDRY, M. DOBIAS-GOFF, J. A. DESMARAIS, V. E. LLERENA and B. D. MURPHY (2011a). Uterine signaling the emergence of the embryo from obligate diapause. Am J Physiol Endocrinol Metab300:E800-808.

LEFEVRE, P. L., M. F. PALIN, G. CHEN, G. TURECKI and B. D. MURPHY (2011b). Polyamines are implicated in the emergence of the embryo from obligate diapause. Endocrinology 152: 1627-1639.

LEFEVRE, P. L., M. F. PALIN and B. D. MURPHY (2011c). Polyamines on the reproductive landscape. Endocr Rev 32: 694-712.

LLERENA-VARGAS, E (2011). Embryonic and uterine characteristics of diapause. MSc memoire, Université de Montréal.

LINDENFORS, P., L. DALEN and A. ANGERBJORN (2003). The monophyletic origin of delayed implantation in carnivores and its implications. Evolution 57: 1952-1956.

LIU, W. M., R. T. PANG, A. W. CHEONG, E. H. NG, K. LAO, K. F. LEE and W. S. YEUNG (2012). Involvement of microRNA lethal-7a in the regulation of embryo implantation in mice. PloSOne 7:e37039.

LOPES, F. L., J. DESMARAIS and M. B.D (2007). A comparative view of prostaglandin action in the uterus. in: Fazleabas, A., Aplin, A., Guidice, L. and Glasser S. The Endometrium, Molecular, Cellular and Clinical Perspectives, 2nd Edition, Chapter 16, Taylor and Francis, Boca Raton. The Endometrium, Molecular, Cellular and Clinical Perspectives, 2nd Edition. pp. 245-259.

LOPES, F. L., J. DESMARAIS, S. LEDOUX, N. Y. GEVRY, P. LEFEVRE and B. D. MURPHY (2006). Transcriptional regulation of uterine vascular endothelial growth factor during early gestation in a carnivore model, Mustela vison. $\mathrm{J}$ Biol Chem 281: 24602-24611.

LOPES, F. L., J. A. DESMARAIS and B. D. MURPHY (2004). Embryonic diapause and its regulation. Reproduction 128: 669-678.

MACDONALD, G. J., D. T. ARMSTRONG and R. O. GREEP (1967). Initiation of blastocyst implantation by luteinizing hormone. Endocrinology 80: 172-176.

MANECKJEE, R. and N. R. MOUDGAL (1975). Induction and inhibition of implantation in lactating rats. $J$ Reprod Fertil 43: 33-40.

MCCORMACK, J. T. and G. S. GREENWALD (1974). Evidence for a preimplantation rise in oestradiol-17beta levels on day 4 of pregnancy in the mouse. $J$ Reprod Fertil 41: 297-301.

MCLAREN, A(1968). Astudy of blastocysts during delay and subsequent implantation in lactating mice. $J$ Endocr 42: 453-463.

MCLAREN, A (1982). The Embryo. in Reproduction in mammals. Vol. 2. 2nd ed. C. R. Austin and R. V. Short, ed. Cambridge University Press, Cambridge. pp. 1-25
MEAD, R. A (1981). Delayed implantation in mustelids, with special emphasis on the spotted skunk. J Reprod Fertil Supp/ 29: 11-24.

MEAD, R. A (1993). Embryonic diapause in vertebrates. J Exp Zool 266: 629-641.

MEAD, R. A., M. M. JOSEPH, S. NEIRINCKX and M. BERRIA (1988). Partial characterization of a luteal factor that induces implantation in the ferret. Biol Reprod 38: 798-803.

MOHAMED, O. A., M. JONNAERT, C. LABELLE-DUMAIS, K. KURODA, H. J. CLARKE and D. DUFORT (2005). Uterine Wnt/beta-catenin signaling is required for implantation. Proc Natl Acad Sci USA 102: 8579-8584.

MOORE, G. P. M (1978). Embryonic diapause in the marsupial Macropus eugenii. Stimulation of nuclear RNA polymerase activity in the blastocyst during resumption of development. J Cellul Phys 94: 31-36.

MOREAU, G. M., A. ARSLAN, D. A. DOUGLAS, J. SONG, L. C. SMITH and B. D. MURPHY (1995). Development of immortalized endometrial epithelial and stroma cell lines from the mink (Mustela vison) uterus and their effects on the survival in vitro of mink blastocysts in obligate diapause. Biol Reprod 53: 511-518.

MURPHY, B. D (1983). Precocious induction of luteal activation and termination of delayed implantation in mink with the dopamine antagonist pimozide. Bio Reprod 29: 658-662

MURPHY, B. D (1992). Progress and challenges in the physiology of reproduction in furbearing carnivores. Norweg J Agri Sci Supp/ 9: 17-29.

MURPHY, B. D (2012). Embryonic diapause: Advances in understanding the enigma of seasonally delayed implantation. Anim Reprod Sci 47(Suppl 6): 1-4

MURPHY, B. D., P. W. CONCANNON, H. F. TRAVIS and W. HANSEL (1981). Prolactin: the hypophyseal factor that terminates embryonic diapause in mink. Bio Reprod 25: 487-491.

MURPHY, B. D., G. B. DIGREGORIO, D. A. DOUGLAS and A. GONZALEZ-REYNA (1990). Interactions between melatonin and prolactin during gestation in mink (Mustela vison). J Reprod Fert 89: 423-429.

MURPHY, B. D. and D. A. JAMES (1974). The effects of light and sympathetic innervation to the head on nidation in mink. J Exp Zool 187: 267-276.

MURPHY, B. D., R. A. MEAD and P. E. MCKIBBIN (1983). Luteal contribution to the termination of preimplantation delay in mink. Biol Reprod 28: 497-503.

MURPHY, B. D. and K. RAJKUMAR (1985). Prolactin as a luteotrophin. Can J Physiol Pharmacol 63: 257-264

NALLASAMY, S., Q. LI, M. K. BAGCHI and I. C. BAGCHI (2012). Msx homeobox genes critically regulate embryo implantation by controlling paracrine signaling between uterine stroma and epithelium. PLoS Genetics 8:e1002500.

NELSON, J. E. and A. GOLDSTONE (1986). Reproduction in Peradorcas-Concinna (Marsupialia, Macropodidae). Wildlife Res 13: 501-505

NEWKIRK, K. D., H. J. MCMILLAN and K. E. WYNNE-EDWARDS (1997). Length of delay to birth of a second litter in dwarf hamsters (Phodopus): evidence for post-implantation embryonic diapause. J Exp Zool 278: 106-114.

NILSSON, O (1974). The morphology of blastocyst implantation. J Reprod Fert 39 187-194.

PAPKE, R. L., P. W. CONCANNON, H. F. TRAVIS and W. HANSEL (1980). Control of luteal function and implantation in the mink by prolactin. JAnim Sci50: 1102-1107.

PARIA, B. C., Y. M. HUET-HUDSON and S. K. DEY (1993). Blastocyst's state of activity determines the "window" of implantation in the receptive mouse uterus. Proc Natl Acad Sci USA 90: 10159-10162.

PARIA, B. C., J. REESE, S. K. DAS and S. K. DEY (2002). Deciphering the cross-talk of implantation: advances and challenges. Science 296: 2185-2188.

PATNODE, K. A. and L. R. CURTIS (1994). 2,2,4,4,5,5- and 3,3,4,4,5,5-hexachlorobiphenyl alteration of uterine progesterone and estrogen receptors coincides with embryotoxicity in mink (Mustela vison). Tox Applied Pharm 127: 9-18.

PRITCHETT-CORNING, K. R., C. B. CLIFFORD and M. F. FESTING (2013). The effects of shipping on early pregnancy in laboratory rats. Birth defects research. Part B, Dev Reprod Tox 98: 200-205

PSYCHOYOS, A(1973). Hormonal control of ovoimplantation. Vitam Horm31:201-256 PSYCHOYOS, A(1986). Uterine receptivity for nidation. Ann NYAcad Sci476: 36-42.

PSYCHOYOS, A (1992). [From Lataste to the "window of implantation": 100 years of fascinating discoveries]. Contraception, fertilité, sexualité 21: 333-338.

PTAK, G. E., J. A. MODLINSKI and P. LOI (2013). Embryonic diapause in humans: time to consider? Reprod Biol Endocrinol 11: 92 
PTAK, G. E., E. TACCONI, M. CZERNIK, P. TOSCHI, J. A. MODLINSKI and P. LOI (2012). Embryonic diapause is conserved across mammals. PloS One 7:e33027.

RENFREE, M. B (1973). Proteins in the uterine secretions of the marsupial Macropus eugenii. Dev Biol 32: 41-49.

RENFREE, M. B (1979). Initiation of development of diapausing embryo by mammary denervation during lactation in a marsupial. Nature 278: 549-551.

RENFREE, M. B (1981). Embryonic diapause in marsupials. J Reprod Fert Suppl 29: 67-78.

RENFREE, M. B (1994). Endocrinology of pregnancy, parturition and lactation in marsupials in Pregnancy and Lactation Part 2: Fetal physiology parturition and Iactation. Vol. 3. 4 ed. G. E. Lamming, ed. Chapman \& Hall, London. pp. 677-766

RENFREE, M. B. and D. R. BLANDEN (2000). Progesterone and oestrogen receptors in the female genital tract throughout pregnancy in tammar wallabies. $J$ Reprod Fert 119: 121-128.

RENFREE, M. B. and G. SHAW (2000). Diapause. Annu Rev Physiol 62: 353-375.

RENFREE, M. B. and C. H. TYNDALE-BISCOE (1973). Intrauterine development after diapause in the marsupial, Macropus eugenii. Dev Biol 32: 28-40.

ROSE, J., J. E. OLDFIELD and F. STORMSHAK (1986). Changes in serum prolactin concentrations and ovarian prolactin receptors during embryonic diapause in mink. Biol Reprod 34: 101-106.

ROSE, J., F. STORMSHAK, J. ADAIR and J. E. OLDFIELD (1983). Prolactin binding sites in the uterus of the mink. Mol Cell Endocrinol 31: 131-139.

SANDELL, M (1990). The evolution of seasonal delayed implantation. Q Rev Biol 65: $23-42$.

SCHULZ, L. C. and J. M. BAHR (2003). Glucose-6-phosphate isomerase is necessary for embryo implantation in the domestic ferret. Proc Natl Acad Sci USA 100: 8561-8566.

SELWOOD, L (1980). A timetable of embryonic development of the dasyurid marsupial Antechinus stuartii (Macleay). Austral J Zool 28: 649-668.

SEMPERE, A (1977). Plasma progesterone levels in the roe deer, Capreolus capreolus. J Reprod Fert 50: 365-366.

SHAW, G. and M. B. RENFREE (1984). Concentrations of oestradiol-17b in plasma and corporea lutea throughout pregnancy in the tammar, Macropus eugenii. $J$ Reprod Fert 72: 29-37.

SHAW, G. and M. B. RENFREE (1986). Uterine and embryonic metabolism after diapause in the tammar wallaby, Macropus eugenii. $J$ Reprod Fert 76: 339-347.

SLAYDEN, O. and F. STORMSHAK (1992). Uterine metabolic activity and steroid receptor concentrations in response to suppressed secretion of PRL in anestrous mink. Gen Comp Endocrinol 88(: 307-315.

SMITH, M. J (1998). Establishment of a captive colony of Bettongia tropica (Marsupialia: Potoroidae) by cross fostering; and observations on reproduction. $J$ Zool Lond 244: 43-50.

SONG, H., H. LIM, B. C. PARIA, H. MATSUMOTO, L. L. SWIFT, J. MORROW, J. V. BONVENTRE and S. K. DEY (2002). Cytosolic phospholipase A2alpha is crucial for 'on-time' embryo implantation that directs subsequent development. Development 129: 2879-2889.

SONG, J. H., A. HOUDE and B. D. MURPHY (1998). Cloning of leukemia inhibitory factor (LIF) and its expression in the uterus during embryonic diapause and implantation in the mink (Mustela vison). Mol Reprod Dev 51: 13-21.

SPINDLER, R. E., M. B. RENFREE and D. K. GARDNER (1996). Carbohydrate uptake by quiescent and reactivated mouse blastocysts. J Exp Zool276: 132-137.

SPINDLER, R. E., M. B. RENFREE and D. K. GARDNER (1999a). Mouse embryos used as a bioassay to determine control of marsupial embryonic diapause. $J$ Exp Zool 283: 590-599.

SPINDLER, R. E., M. B. RENFREE, G. SHAW and D. K. GARDNER (1998). Reactivating tammar wallaby blastocysts oxidise glucose. Biol Reprod 58: 1425-1431.

SPINDLER, R. E., M. B. RENFREE, G. SHAW and D. K. GARDNER (1999b). Reactivating tammar wallaby blastocysts oxidize fatty acids and amino acids. $J$ Reprod Fert 115: 79-86.

STEWART, C. L., P. KASPAR, L. J. BRUNET, H. BHATT, I. GADI, F. KONTGEN and S. J. ABBONDANZO (1992). Blastocyst implantation depends on maternal expression of leukaemia inhibitory factor. Nature 359: 76-79.

STEWART, F. and C. H. TYNDALE-BISCOE (1982). Prolactin and luteinizing hormone receptors in marsupial corpora lutea: relationship to control of luteal function. $J$ Endocrinol 92: 63-72.
STOUFFLET, I., M. MONDAIN-MONVAL, P. SIMON and L. MARTINET (1989) Patterns of plasma progesterone, androgen and oestrogen concentrations and in-vitro ovarian steroidogenesis during embryonic diapause and implantation in the mink (Mustela vison). J Reprod Fert 87: 209-221.

THOM, M. D., D. D. JOHNSON and D. W. MACDONALD (2004). The evolution and maintenance of delayed implantation in the mustelidae (Mammalia: Carnivora). Evolution. Int J Org Evolution 58: 175-183.

THORNBER, E. J., M. B. RENFREE and G. I. WALLACE (1981). Biochemical studies of intrauterine components of the tammar wallaby Macropus eugenii during pregnancy. J Embryol Exp Morph 62: 325-338.

TYNDALE-BISCOE, C. H (1970). Resumption of development by quiescent blastocysts transferred to primed, ovariectomized recipients in the marsupial, Macropus eugenii. J Reprod Fert 23: 25-32.

TYNDALE-BISCOE, C. H (1978). Hormonal control of embryonic diapause and reactivation in the tammar wallaby. Ciba Found Symp 64: 173-190.

TYNDALE-BISCOE, C. H (2005). Life of Marsupials. CSIRO Publishing, Collingwood Australia

TYNDALE-BISCOE, C. H. and J. P. HEARN (1981). Pituitary and ovarian factors associated with seasonal quiescence of the tammar wallaby, Macropus eugenii. $J$ Reprod Fert 63: 225-230.

TYNDALE-BISCOE, C. H. and L. A. HINDS (1984). Seasonal patterns of circulating progesterone and prolactin and response to bromocriptine in the female tammar, Macropus eugenii. Gen Comp Endocrinol 53: 58-68.

TYNDALE-BISCOE, C. H. and L. A. HINDS (1992). Components of the melatonin message in the response to photoperiod of the tammar wallaby (Macropus eugenii). J Pineal Res 12: 155-166.

TYNDALE-BISCOE, C. H., L. A. HINDS and S. J. MCCONNELL (1986). Seasonal breeding in a marsupial: opportunites of a new species for an old problem. Rec Prog Hormone Res 42: 471-512.

TYNDALE-BISCOE, C. H. and M. B. RENFREE (1987). Reproductive Physiology of Marsupials. Cambridge University, Cambridge.

VAN DER HORST, P. H., Y. WANG, M. VAN DER ZEE, C. W. BURGER and L. J. BLOK (2012). Interaction between sex hormones and WNT/beta-catenin signal transduction in endometrial physiology and disease. Mol Cell Endocrinol 358: 176-184.

VASQUEZ, Y. M. and F. J. DEMAYO (2013). Role of nuclear receptors in blastocyst implantation. Sem. Cell Dev Biol 24: 724-735.

WALLACE, H. M., A. V. FRASER and A. HUGHES (2003). A perspective of polyamine metabolism. Biochem J 376: 1-14.

WANG, H., H. MATSUMOTO, Y. GUO, B. C. PARIA, R. L. ROBERTS and S. K. DEY (2003). Differential G protein-coupled cannabinoid receptor signaling by anandamide directs blastocyst activation for implantation. Proc Am Physio Soc. 100: 14914-14919

WEITLAUF, H. M (1974). Metabolic changes in the blastocysts of mice and rats during delayed implantation. J Reprod Fert 39: 213-224.

WEITLAUF, H. M (1978). Factors in mouse uterine fluid that inhibit the incorporation of [3H] uridine by blastocysts in vitro. J Reprod Fert 52: 321-325.

WEITLAUF, H. M. and G. S. GREENWALD (1968). Survival of blastocysts in the uter of ovariectomized mice. J Reprod Fert 17: 515-520.

WHITTEN, W. K (1957). The effect of progesterone on the development of mouse eggs in vitro. J Endocrinol 16: 80-85.

YOO, H.-J., D. H. BARLOW and H. J. MARDON (1997). Temporal and spatial regulation of expression of heparin-binding epidermal growth factor-like growth factor in the human endometrium: a possible role in blastocyst implantation. Developmental Genetics 21: 102-108.

YOSHINAGA, K (1988). Uterine Receptivity for Blastocyst Implantation. Ann NY Acad Sci 541: 424-431.

YOSHINAGA, K. and C. E. ADAMS (1966). Delayed implantation in the spayed, progesterone treated adult mouse. J Reprod Fert 12: 593-595.

ZHANG, C. and B. D. MURPHY (2013). Progesterone is critical for the development of mouse embryos. Endocrine in press. DOI 10.1007/s12020-013-0140-7.

ZHANG, H., D. LI, C. WANG and V. HULL (2009). Delayed implantation in giant pandas: the first comprehensive empirical evidence. Reproduction 138: 979-986.

ZHANG, S., S. KONG, J. LU, Q. WANG, Y. CHEN, W. WANG, B. WANG and H. WANG (2013). Deciphering the molecular basis of uterine receptivity. Mol Reprod Dev 80: 8-21. 
174 J.C. Fenelon et al.

ZHAO, T., K. J. GOH, H. H. NG and L. A. VARDY (2012). A role for polyamine regulators in ESC self-renewal. Cell Cycle 11: 4517-4523.

ZHAO, Y. C., Y. J. CHI, Y. S. YU, J. L. LIU, R. W. SU, X. H. MA, C. H. SHAN and Z M. YANG (2008). Polyamines are essential in embryo implantation: expression and function of polyamine-related genes in mouse uterus during peri-implantation

period. Endocrinology 149: 2325-2332.

ZWIERZCHOWSKI, L., M. CZLONKOWSKA and A. GUSZKIEWICZ (1986). Effect of polyamine limitation on DNA synthesis and development of mouse preimplantation embryos in vitro. J Reprod Fert 76: 115-121. 


\section{Further Related Reading, published previously in the Int. J. Dev. Biol.}

\section{Local regulation of implantation at the human fetal-maternal interface}

Evdokia Dimitriadis, Guiying Nie, Natalie J. Hannan, Premila Paiva and Lois A. Salamonsen Int. J. Dev. Biol. (2010) 54: 313-322

http://dx.doi.org/10.1387/ijdb.082772ed

Implantation: molecular basis of embryo-uterine dialogue

B C Paria, H Song and S K Dey

Int. J. Dev. Biol. (2001) 45: 597-605

http://www.intjdevbiol.com/web/paper/11417904

DNA methylation and polyamines in embryonic development and cancer

O Heby

Int. J. Dev. Biol. (1995) 39: 737-757

http://www.intjdevbiol.com/web/paper/8645558

5 yr ISI Impact Factor $(2011)=2.959$
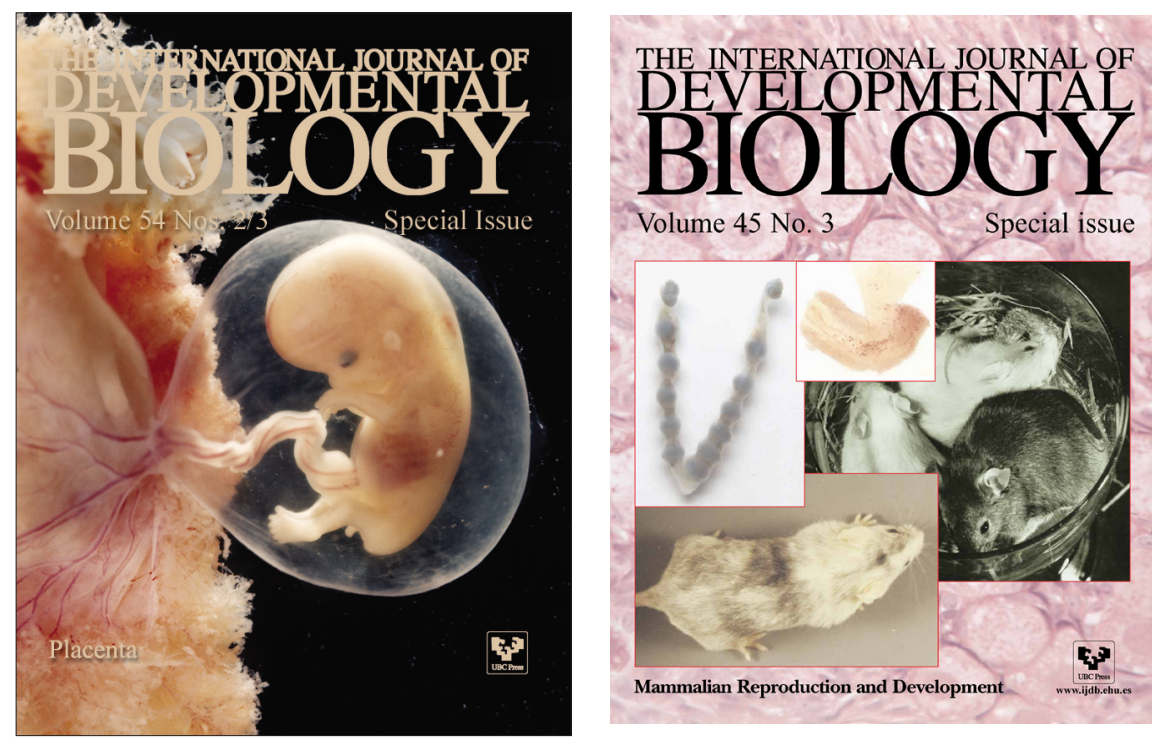

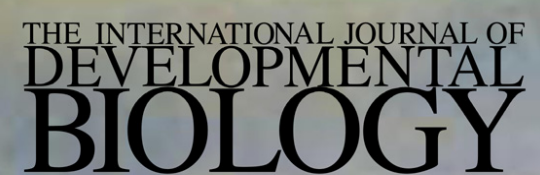

Volume 47 Nos. $7 / 8$

Special Issue

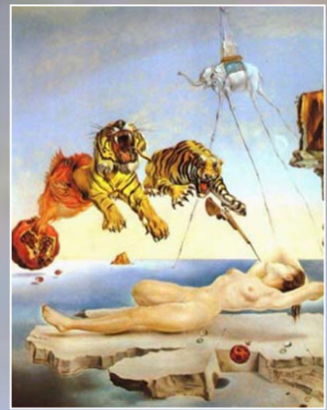

Evolution \& Development 